\title{
The Evaluation of CEIT Teacher Candidates in Terms of Computer Games, Educational Use of Computer Games and Game Design Qualifications
}

\author{
Hakkı BAĞCI*
}

\author{
Ahmet Naci ÇOKLAR ${ }^{* *}$
}

Accepted: 28 March 2014

\begin{abstract}
Computer games have an important usage potential in the education of today's digital student profile. Also computer teachers known as technology leaders in schools are the main stakeholders of this potential. In this study, opinions of the computer teachers about computer games are examined from different perspectives. 119 computer teacher candidates participated in this study, and the data were collected by a questionnaire. As a result of this study, computer teacher candidates have a positive thinking about the usage of computer games in education and they see themselves qualified for the analysis and design of educational games. But they partially have negative attitudes about some risks like addiction and lose of time. Also the candidates who attended the educational game courses and play games from their mobile phones have more positive opinions, and they see themselves more qualified than others. Males have more positive opinions about computer games than females, but in terms of educational games and the analysis and design of the computer games, there is no significant difference between males and females.
\end{abstract}

Keywords: computer game, educational games, computer game design, computer teacher candidate.

\section{Extended Abstract}

Purpose and Significance: The aim of this study is to define the opinions of computer teacher candidates about computer games and the use of computer games for educational purposes. Also it is aimed that whether the views of computer teacher candidates about computer games, educational computer games and the qualifications for analyzing and designing computer games show difference according to their situations of taking computer courses, their genders and playing games on their mobile phones or not. This is an important study because it will define the teacher candidates' views about computer games and educational computer games from the department of Computer Education and Instructional Technologies which has an important role in this subject area and the main department of computer teacher training. Also this study will define the needs and trends for this subject area, and the educational game design expert staff profile for Turkey.

Methods: Qualitative data were used in this study. $3^{\text {rd }}$ and $4^{\text {th }}$ class computer teacher candidates in the semester of 2012-2013 from Sakarya University participated in this study. There are $4^{\text {th }}$ class students who took the computer game courses, and $3^{\text {rd }}$ class students who did not take this course. Totally, 119 teacher candidates participated in the

\footnotetext{
* Corresponding Author: Assist. Prof. Dr., Sakarya University, Sakarya, Turkey, hakkibagci@hotmail.com

Assist. Prof. Dr., Necmettin Erbakan University, Konya, Turkey, acoklar@konya.edu.tr
} 
study. There are 27 items in the questionnaire which was developed by the researchers as the data collection tool. 6 items defines the views of computer games, 15 items defines the views of the use of computer games for educational purposes and the last 6 items defines the views of computer game design qualifications. The internal consistency coefficient was calculated as 0.88 for this questionnaire which contains 27 items and 3 sub dimensions. Arithmetic mean, percentage and frequency as descriptive statistics were used in order to define the views of computer teacher candidates about computer games. On the other hand, independent samples t-test is used to define whether there is a difference between candidates in terms of taking computer game course, gender and playing games on mobile phones or not. Significance level is accepted as 0.05. SPSS 17.0 (Statistical Package for Social Sciences) statistics program was used to analyze the data.

Results: Computer teacher candidates have some negative opinions about computer games such as addiction, lose of time etc. However, they have positive opinions about the use of computer games for educational purposes. They see themselves as qualified enough for analyzing, designing and choosing computer games for education. There is a statistically significant difference between the candidates' opinions of computer games in terms of taking computer game course. Also the teacher candidates who play games on their mobile phones have more positive opinions about computer games than other candidates who do not play games on mobile phones. In terms of gender, there is a statistically significant difference about the general subject area of computer games that females have more negative opinions than males do about them.

Discussion and Conclusions: The aim of this study is to define the views of computer teacher candidates about computer games and the use of computer games for educational purposes. Games are important educational tools that transfer knowledge and information to the next generations. Game is the best tool that helps students to express themselves better, and teachers and parents can understand their feelings better with games. Also game is an educational tool that students learn on their own (Çoban \& Nacar, 2006). There are some important responsibilities for the teachers who will use computer games for education. Teachers should use games and computer games where required in order to achieve the educational goals. This study shows that computer teacher candidates have some negative opinions about computer games but they support the use of computer games for educational purposes. Computer game courses help students to change their minds about the computer games. So it can be said that computer education is important for this way of thinking. Also it is important that playing games on mobile phones changes the views of teacher candidates about computer games. They have technological devices that give the opportunity of playing games. As they experienced the game playing, their opinions were affected from this situation. Thus, it may be recommended that educational game courses containing different technologies should be given to the computer teacher candidates. 


\section{Bilgisayar Oyunları, Eğitsel Kullanımları ve Tasarım Yeterlikleri Açısından BÖTE Öğretmen Adaylarının Değerlendirilmesi}

\author{
Hakkı BAĞCI ${ }^{*}$
}

\author{
Ahmet Naci ÇOKLAR ${ }^{* *}$
}

Makale Gönderme Tarihi: 19 Temmuz 2013

Makale Kabul Tarihi: 28 Mart 2014

ÖZET: Bilgisayar oyunları, günümüz dijital öğrenci profilinin eğitiminde önemli bir kullanım potansiyeline sahiptir. $\mathrm{Bu}$ potansiyelin kullanımında öne çıkan bireylerden birisi de okullarda bir teknoloji lideri olan bilgisayar öğretmenleridir. Bu araştırmada, bilgisayar öğretmenlerinin bilgisayar oyunlarına yönelik görüşleri farklı boyutlardan ele alınmıştır. Araştırma kapsamında 119 bilgisayar öğretmen adayına ulaşılmış, geliştirilen anketle veri toplanmıştır. Araştırma sonucunda bilgisayar öğretmen adaylarının eğitsel anlamda bilgisayar oyunlarının kullanımı konusunda olumlu düşünceye sahip oldukları ve eğitsel oyunların tasarımı ve analizi konusunda kendilerini yeterli gördükleri, ancak bilgisayar oyunları konusunda bağımlılık riski, zaman kaybı gibi bazı konularda kısmen olumsuz görüşe sahip oldukları sonucuna ulaşılmıştır. Ayrıca eğitsel oyun dersi alan öğrenciler ile cep telefonundan oyun oynayan öğrencilerin bilgisayar oyunlarına yönelik bazı boyutlarda görüşlerinin daha olumlu olduğu ve kendilerini daha yeterli gördükleri sonucuna ulaşılmıştır. Cinsiyet açısından sadece bilgisayar oyunları geneli için erkekler kızlardan oyunlar konusunda daha olumlu görüş bildirirken, bilgisayar oyunlarının eğitim amaçlı kullanımı ve eğitsel oyunların tasarımı/analizi açısından bir farklılık bulunmamaktadır.

Anahtar sözcükler: bilgisayar oyunu, eğitsel oyunlar, bilgisayar oyun tasarımı, BÖTE öğretmen adayı.

\section{Giriş}

Günümüz dünyasında teknoloji hızla gelişmekte ve ortaya çıkan eğitim-öğretim sorunlarının çözümünde, eğitim etkililiğinin artırılmasında ortaya çıkan yeni teknolojilerden yararlanılmaktadır. Eğitim-öğretim ortamına entegre edilen, eğitim kalitesinin artırılmasında kullanılan yeni teknolojilerden biri de bilgisayar oyunlarıdır. Bilgisayar oyunları insanlar tarafından gönüllü olarak oynanan, eğlenceli, gerçek dünyadan bağımsız ve içerisinde bulundurduğu kurallar ile sınırlandırılmış eğlence ortamlarıdır (Garris, Ahlers ve Driskell, 2002). Özellikle eğlence boyutu ve gönüllü olarak oynanması, bilgisayar oyunlarını çocukların öğrenmesinde cazip hale getirmektedir. Bunun haricinde oyunlar sosyal gelişim açısından da önem taşımaktadır. İyi tasarlanmış ve pedagojik anlamda yeterli bilgisayar oyunları diğer oyunlar gibi sosyal gelişimi hızlandırırken eğlendirmekte, oyun oynayan çocuklara tartışma ve fikir alışverişinde bulunma becerisi kazandırmaktadır (Ward, 2004).

Eğitim-öğretim ortamlarında bilgisayar oyunlarının kullanılması diğer bir deyişle eğitsel bilgisayar oyunları, bilgisayar oyunlarının motive edici ve eğlendirici özelliklerini barındırmakta, öğretimsel ya da eğitsel amaçlı olarak diğer öğretim yöntemlerinin alternatifi, tamamlayıcısı ve zenginleștiricisi olarak kullanılabilmektedir (Çankaya ve Karamete, 2008). Diğer bir ifade ile hazırlanan konu alanına özgü bilgileri içinde barındıran eğitsel bilgisayar oyunları hem öğrencinin hoş vakit geçirmesine yardım etmekte, hem de onların yeteneklerini geliştirmeye yardımcı olmaktadır. Eğitsel bilgisayar oyunları öğrencilerin yaratıcılığını, karar verme yeteneğini, hayal gücünü

\footnotetext{
* Sorumlu Yazar: Yard. Doç. Dr., Sakarya Üniversitesi, Sakarya, hakkibagci@hotmail.com

** Yrd. Doç. Dr., Necmettin Erbakan Üniversitesi, acoklar@konya.edu.tr
} 
geliştirmekte, aynı zamanda onlara hızlı düşünme becerileri kazandırmaktadır(Altun, 2000).Günümüzde bilgisayar oyunları eğitim ile eğlenceyi birleştirmesi açısından önem taşımaktadır. Ayrıca neredeyse bütün derslerin oyunlarla öğretiminin mümkün olması eğitsel bilgisayar oyunlarının önemini artırmaktadır.

Sağladığı avantajlar ile birlikte internetin yaygınlaşması, akıllı cep telefonları, tablet bilgisayarlar gibi gelişen teknolojiler de bilgisayar oyunlarının eğitim amaçlı kullanımını artıracak niteliktedir. Ancak bir bilgisayar oyununun eğitsel amaçlı bir oyun olabilmesi için bazı bileşenlerden oluşması, bu bileşenlere göre tasarlanıp planlanması gerekir. Prensky (2001) bir oyuna eğitsel özellik katan bileşenleri 6 başlıkta toplamıştır:

1. Kurallar: Kurallar oyunların sınırlarını çizerler ve bizlere hedefimize ulaşmak için çeşitli yollar sunarlar.

2. Hedef ve amaçlar: Hedef ve amaç, oyuncuda görev duygusu yaratır ve gönüllü olarak oyunu oynamasını, zaman ve emek harcamasını sağlar.

3. Dönütler (geri bildirimler): Hedefin karşısında kullanıcının nasıl ilerlediği dönütler sayesinde bildirilir. Oyunda kullanıcının yaptığı bir şeye karşlık bir durum değiştiğinde geri bildirim verilir.

4. Mücadele / yarış / meydan okuma / karşıtlık: Mücadele, yarış, meydan okuma ve karşıtlık oyunda çözülmeye çalışılan problemdir. Kullanıcı oyun içerisinde gerçek tehlikeler ile karşı karşıya kalmadan, gerçek yaşamdaki gibi korku ve heyecan duyabilir. $\mathrm{Bu}$ da, onu motive eder ve o oyunu sürdürmesini ve tamamlamasını sağlar.

5. Etkileşim: Etkileşim iki açıdan ele alınır. İlki, oyuncuların ya da bilgisayarın etkileşimidir ki, buna dönüt denilebilir. İkincisi ise; oyuncuların oyunu oynarken birbirleri ile oluşturdukları sosyal durumdur.

6. Sunum veya hikâye: Oyunun ne hakkında olduğudur. Oyunun hikâyesi oyunun başında doğrudan verilebileceği gibi oyunun içerinde dolaylı olarak da verilebilir.

Akpınar (1999)'da bilgisayar oyunlarının eğitsel kabul edilebilmesi için tasarım ve programlanmasında dikkat edilmesi gereken Prensky (2001) tarafindan ifade edilen başlıklara benzer konuları sekiz başlıkta toplamıştır.

Bilgisayar oyunları, günümüz öğrencileri tarafindan televizyon, cep telefonu, tablet bilgisayar, bilgisayar vb. araçlar üzerinden yaygın olarak kullanılmaktadır. Her bilgisayar oyununun, eğitsel oyun olarak kabul edilememesinin nedeni yukarıda ifade edilen özellikleri kapsamamasıdır. Bu açıdan özellikle ilk, orta ve lise eğitiminde ihtiyaç duyulan eğitsel oyunların kullanımı ve tasarımı konusunda öğretim teknologlarına ihtiyaç duyulmaktadır. Ülkemizde Bilgisayar ve Öğretim Teknolojileri Eğitimi (BÖTE) öğretmenlerinin bu yönde de misyonu bulunmaktadır.

\section{İlgili Araștırmalar}

Yapılan literatür taramasında doğrudan BÖTE bölümü öğretmen adaylarının bilgisayar oyunlarına yönelik görüşleri veya yeterliklerine yönelik bir literatüre ulaşılamamıştır. $\mathrm{Bu}$ doğrultuda bilgisayar oyunları konusunda öğrencilere yönelik 
yapılan araştırmalara odaklanılmıştır. Horzum (2011) ilköğretim birinci kademedeki öğrencilerin bilgisayar oyun bağımlılığı düzeylerini incelemiştir. Yaptığı araştırma sonucunda erkek öğrencilerin kız öğrencilere oranla ve 4. sınıf öğrencilerin 3. ve 5. sınıf öğrencilere göre daha yüksek oyun bağımlısı olduğunu bulmuştur. Onay, Tüfekçi ve Çağıltay (2005) tarafından üniversite öğrencilerinin bilgisayar oyunu oynama alışkanlıkları ve oyun tercihlerini belirlemek için yapılan çalışmada, üniversite öğrencileri arasında kız öğrencilerin erkek öğrencilere göre oyun oynama seviyelerinin daha düşük olduğu tespit edilmiştir. Çankaya ve Karamete (2008) eğitsel bilgisayar oyunlarının öğrencilerin matematik dersine ve eğitsel bilgisayar oyunlarına yönelik tutumlarına etkisini incelemişlerdir. Yapılan çalışmanın sonucunda öğrencilerin eğitsel bilgisayar oyunlarına olan tutumları pozitif çıkmıştır. Kert ve Kuzu (2006), bilgisayar oyunlarının öğrenciler üzerindeki etkinliğini sorgulamış ve lise düzeyindeki öğrencilerin oyun tercihleri ve oyun oynama alışkanlıklarını incelemişlerdir. Çalışmanın sonucunda, öğrencilerin bilgisayar oyunlarına ilgisinin üst düzeyde olduğu tespit edilmiştir. Kula ve Erdem (2005), araştırmalarında öğretimsel bilgisayar oyunlarının temel aritmetik işlem becerilerinin gelişimine etkisini incelemiştir. Yapılan çalışma sonucunda öğretimsel bilgisayar oyununun 4. ve 5. sınıf öğrencilerinin temel aritmetik işlem becerilerinin gelişimine etkisinin istatistiksel olarak anlamlı olmadığı, buna karşın cinsiyetin önemli bir faktör olduğu ve kız öğrencilerin erkek öğrencilere oranla akademik ortalamalarında daha fazla artış olduğu sonuçları bulunmuştur.

\section{Araştırmanın Önemi}

Yapılan araştırmaların oyun bağımlılığı, oyun oynama alışkanlığı ve tercihleri, derse yönelik tutumlar üzerine etkisi, akademik başarıya etkisi şeklinde olduğu söylenebilir. Oyunların giderek artan popülaritesine karşın, eğitim açısından hak ettiği yerde olmadığı söylenebilir. Bu açıdan oyun tasarımı konusunda yetkinliği olan bireylerin düşüncelerinin ortaya konması, yeterliklerinin belirlenmesi önemlidir. Türkiye'de Eğitim Fakültelerinde yer alan Bilgisayar ve Öğretim Teknolojileri Eğitimi (BÖTE) Bölümü öğrencileri bilgisayar oyunu üretimi ve kullanımı konusunda Öğretim Teknoloğu sıfatı ile bu konuya en yatkın bireyler olarak ön plana çıkmaktadırlar. Araştırma, tasarımcı konumunda olan BÖTE bölüm öğretmen adaylarının bilgisayar oyunları ve eğitsel amaçlı oyun tasarımı ile kullanımı konusundaki düşüncelerinin belirlenmesi, eğitsel oyun tasarım uzmanlığı konusundaki Türkiye'deki profilin çizilmesi açısından önemlidir.

\section{Araştırmanın Amacı}

$\mathrm{Bu}$ araştırmanın amacı, bilgisayar öğretmen adaylarının bilgisayar oyunları ve bilgisayar oyunlarının eğitim amaçlı kullanımına yönelik görüşlerini belirlemektir. Bu amaçla aşağıdaki sorulara yanıtlar aranmıştır.

1. Bilgisayar öğretmen adaylarının genel olarak bilgisayar oyunları, bu oyunların eğitim amaçlı kullanımı ve eğitsel oyun tasarımı ve analizine yönelik yeterlikleriyle ilgili görüşleri nedir? 
2. Bilgisayar öğretmen adaylarının bilgisayar oyunları, eğitim amaçlı bilgisayar oyunu kullanımı ve eğitsel oyun tasarım/analiz yeterliklerine yönelik görüşleri

a. bilgisayar dersi alma durumlarına,

b. cinsiyetlerine ve

c. cep telefonundan oyun oynama durumlarına

göre farklılaşmakta mıdır?

\section{Yöntem}

$\mathrm{Bu}$ çalışma bilgisayar öğretmen adaylarının bilgisayar oyunlarına yönelik görüşlerini ortaya koymayı amaçlamaktadır. Araştırma verilerini toplamak için tarama modeli kullanılmıştır. Ayrıca alt amaçlar doğrultusunda tekil ve ilişkisel tarama modellerinin her ikisinden de yararlanılmıştır.

\section{Katılımcılar}

Araştırmanın katılımcılarını 2012-2013 eğitim öğretim yılında Sakarya Üniversitesinde öğrenim gören 3. ve 4. (son) sınıf bilgisayar öğretmen adayları oluşturmaktadır. Bilgisayar oyunları ile ilgili eğitim alan ve eğitim sürecini tamamlayan 4. sınıf öğrenciler ile bu konuda henüz eğitim almamış olan 3. sınıf öğrencileri araştırmaya dâhil edilmiştir. Araştırma kapsamında örneklem alınmamış, toplam 119 (61-4. sınıf ve 58-3.sınıf) öğretmen adayına ulaşılmıştır. 74'ü (\%62) erkek, 45'i (\%38) ise kadındır. Ayrıca araştırmaya katılan öğrencilerin 76'sı (\%64) cep telefondan oyun oynadığını belirtirken, 43’ü (\%36) cep telefonundan oyun oynamadığını belirtmiştir.

\section{Veri Toplama Aracı}

Araştırmada veri toplamak amacı ile iki bölümden oluşan bir anket geliştirilmiştir. İlk bölümde kişisel bilgiler, ikinci bölümde ise bilgisayar oyunlarına yönelik görüşleri yordayan ve beşli likert şeklinde ifade edilen maddeler yer almaktadır. Öncelikle yapılan benzer araştırmalar incelenerek bir madde havuzu oluşturulmuştur. Geliştirilen taslak kapsam geçerliği için eğitim teknolojileri alanında görev yapan üç farklı alan uzmanına sunulmuş, dönütler sonrasında iki madde düzeltilirken, dört yeni madde ilave edilmiştir. Bilgisayar öğretmenliği bölümünden iki öğrenciye okutulan ankete son şekli verilmiştir. Nihai anket formunda 27 madde yer almıştır. Bu maddelerden ilk altısı bilgisayar oyunlarına, 15'i bu oyunların eğitim amaçlı kullanımına, son altısı ise bu oyunların tasarlanabilme yeterliğine yönelik öğrencilerin görüşlerini belirlemek amacıyla hazırlanmıştır. 27 madde ve üç alt boyuttan oluşan anketin uygulama sonrası iç tutarlık katsayısı 0.88 olarak hesaplanmıştır.

\section{Verilerin Analizi ve Yorumlanması}

Yeterli sayıda çoğaltılan veri toplama aracı, araştırmacılar tarafından öğrencilere uygulanmıştır. Beşli likert şeklindeki anket maddelerinin bilgisayar ortamına aktarılmasında "1 - hiç katılmıyorum", "2- katılmıyorum”, “3- kararsızım", "4katılıyorum" ve "5- kesinlikle katılıyorum” şeklinde bir puanlama yapılmıştır. Anket 
maddelerinin puanlanmasında ters olan 2. ve 6. maddeler tersten puanlanmıştır. Bilgisayar öğretmen adaylarının bilgisayar oyunlarına yönelik görüşlerini değerlendirebilmek için ortalama değer üzerinden üç değerlendirme aralığg ve kriteri belirlenmiştir (Tablo 1).

Tablo 1

Bilgisayar Oyunlarına Yönelik Görüşleri Değerlendirme Ölçütleri

\begin{tabular}{lcc}
\hline & \multicolumn{2}{c}{ Değerlendirme Kriteri } \\
Değerlendirme Aralığı & $\begin{array}{c}\text { Genel ve Eğitim Amaçlı Oyun } \\
\text { Kullanım Boyutları }\end{array}$ & $\begin{array}{c}\text { Eğitsel Oyun } \\
\text { Tasarımı Boyutu }\end{array}$ \\
\hline $1.00-2.33$ arası & Olumsuz & Yetersiz \\
$2.34-3.66$ arası & Kismen olumlu & Kısmen Yeterli \\
$3.67-5.00$ arası & Olumlu & Yeterli \\
\hline
\end{tabular}

Bilgisayar öğretmen adaylarının bilgisayar oyunlarına yönelik görüşlerinin belirlenmesi için betimsel istatistiklerden aritmetik ortalama, yüzde ve frekanstan yararlanılmıştır. Diğer yandan öğretmen adaylarının bilgisayar oyunu eğitimi alma, cinsiyet ve cep telefonundan oyun oynama durumlarına göre oyunlara yönelik görüşlerinin farklılaşıp farklılaşmadığını belirlemek için bağımsız örneklem t-testi kullanılmıştır. Verilerin analizlerde anlamlılık düzeyi .05 olarak alınmıştır. Ayrıca istatistiksel çözümlemelerde SPSS 17.0 (Statistical Package for the Social Sciences) paket programından yararlanılmıştır.

\section{Bulgular ve Yorumları}

Araştırma kapsamında bilgisayar öğretmen adaylarının bilgisayar oyunlarına yönelik görüşleri ve bu görüşlerinin farklı değişkenler açısından değerlendirilmesi başlıklar şeklinde verilmiştir.

\section{Bilgisayar Öğretmen Adaylarının Bilgisayar Oyunlarına Yönelik Görüşleri}

Bilgisayar öğretmen adaylarının bilgisayar oyunlarına, eğitsel amaçlı bilgisayar oyunu kullanımına, eğitsel amaçlı bilgisayar oyunu tasarlamaya yönelik görüşleri üç farklı boyutta ele alınmıştır (Tablo 2). 
Tablo 2

Alt Boyutları Açısından Bilgisayar Oyunları Hakkındaki Görüşler

\begin{tabular}{clcc}
\hline & Alt Boyutlar & $\overline{\mathrm{X}}$ & ss \\
\hline 1 & Bilgisayar Oyunları Geneli & 3.58 & .53 \\
2 & Eğitim Amaçlı Kullanımı & 3.88 & .61 \\
3 & Tasarım ve Analiz & 4.00 & .64 \\
\hline
\end{tabular}

Bilgisayar öğretmen adayları bilgisayar oyunlarının kullanımını ( $\bar{X}=3.58)$ kısmen olumlu bulurken, eğitim amaçlı bilgisayar oyunu kullanımını ( $\bar{X}=3.88$ ) olumlu bulmaları dikkat çekicidir. Diğer yandan öğretmen adayları bu oyunların tasarımı konusunda kendilerini ( $\bar{X}=4.00$ ) yeterli gördükleri de Tablo 3’ten görülmektedir (Tablo 2). Bilgisayar öğretmen adayları bilgisayar oyunlarını genel olarak olumlu bulmazken, eğitim amaçlı kullanımı konusunda olumlu görüş bildirmeleri manidardır. Dikkat çekici bir konu olarak öğretmen adayları oyun tasarlama ve analiz etme konusunda kendilerini yeterli bulmaktadır. Tablo 3'te alt boyutları oluşturan maddeler ve bu maddelere ait analiz sonuçları verilmiştir.

Tablo 3

Bilgisayar Öğretmen Adaylarının Bilgisayar Oyunlarına Yönelik Görüşleri

\begin{tabular}{|c|c|c|c|c|}
\hline & No & Maddeler & $\bar{x}$ & SS \\
\hline \multirow{6}{*}{ 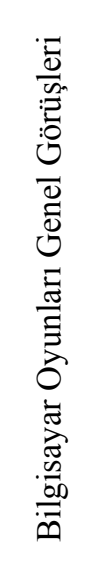 } & 1 & Bilgisayar oyunları hayatımızın bir parçası haline gelmiştir. & 3.49 & 1.27 \\
\hline & 2 & $\begin{array}{l}\text { Bilgisayar oyunu oynamak öğrencileri bilgisayara ve oyuna karşı } \\
\text { bağımlı hale getirir. }(*)\end{array}$ & 3.25 & .83 \\
\hline & 3 & $\begin{array}{l}\text { Bilgisayar oyunu oynamak öğrencilerin bir şeyler öğrenmesine karşı } \\
\text { merak uyandırır. }\end{array}$ & 3.36 & .98 \\
\hline & 4 & $\begin{array}{l}\text { Bilgisayar oyunlarının bir arkadaş grubu veya aile ile birlikte } \\
\text { oynanması öğrencilerin sosyal becerilerinin gelişmesini sağlayabilir. }\end{array}$ & 3.55 & .94 \\
\hline & 5 & $\begin{array}{l}\text { Bilgisayar oyunu her yaş grubundaki öğrenciler için uygun bir } \\
\text { etkinliktir. }\end{array}$ & 3.01 & 1.29 \\
\hline & 6 & Bilgisayar oyunu öğrencilerin zaman kaybına neden olabilir. (*) & 3.84 & 1.09 \\
\hline \multirow{4}{*}{ 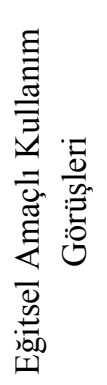 } & 7 & Bilgisayar oyunu eğitimde kullanılabilir. & 4.29 & .85 \\
\hline & 8 & $\begin{array}{l}\text { Bilgisayar oyunlarının eğitimde kullanılması öğrencilerin derse olan } \\
\text { ilgisini artırabilir. }\end{array}$ & 4.16 & .83 \\
\hline & 9 & $\begin{array}{l}\text { Derslerde bilgisayar oyunlarının kullanılması öğrencilerin öğrenmesini } \\
\text { kolaylaştırabilir. }\end{array}$ & 4.24 & .86 \\
\hline & 10 & $\begin{array}{l}\text { Derslerde bilgisayar oyunlarının kullanılması öğrencilerin kendilerini } \\
\text { daha rahat hissetmesini sağlayabilir. }\end{array}$ & 3.83 & .94 \\
\hline
\end{tabular}


Tablo 3'ün devamı

\begin{tabular}{|c|c|c|c|c|}
\hline & No & Maddeler & $\overline{\mathrm{x}}$ & ss \\
\hline \multirow{11}{*}{ 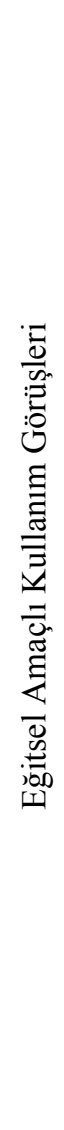 } & 11 & $\begin{array}{l}\text { Derslerde bilgisayar oyunu öğretime yardımcı olarak kullanıldı̆̆ında } \\
\text { öğrenme üzerinde pozitif etki sağlayabilir. }\end{array}$ & 4.08 & .85 \\
\hline & 12 & $\begin{array}{l}\text { Derslerde öğrencilerin boş zamanlarını doldurmak için bilgisayar } \\
\text { oyunu kullanılması öğrenmede pozitif etkili olabilir. }\end{array}$ & 3.55 & 1.05 \\
\hline & 13 & $\begin{array}{l}\text { Derslerde bilgisayar oyununun kullanılması öğrencileri yarış ortamında } \\
\text { bulundurduğu için öğrenmede pozitif etkili olabilir. }\end{array}$ & 3.53 & .99 \\
\hline & 14 & Bilgisayar oyunları tüm öğretim kademelerinde uygulanabilir. & 3.48 & 1.13 \\
\hline & 15 & Bilgisayar oyunları tüm dersler için uygulanabilir. & 3.48 & 1.18 \\
\hline & 16 & $\begin{array}{l}\text { Bilgisayar oyunu derslerin müfredat programlarına ve amaçlarına } \\
\text { uygun bir şekilde kullanılabilir. }\end{array}$ & 4.05 & .73 \\
\hline & 17 & $\begin{array}{l}\text { Derslerde bilgisayar oyunu kullanılması öğrencilerin kendilerine } \\
\text { güvenmelerini sağlayabilir. }\end{array}$ & 3.65 & .97 \\
\hline & 18 & $\begin{array}{l}\text { Derslerde bilgisayar oyunu kullanılması öğrencilerin kendi kendine } \\
\text { öğrenmelerini kolaylaştırabilir. }\end{array}$ & 3.92 & .72 \\
\hline & 19 & $\begin{array}{l}\text { Derslerde bilgisayar oyunu kullanılması öğrencilerin başarılarının } \\
\text { artmasına yardımcı olabilir. }\end{array}$ & 3.92 & .85 \\
\hline & 20 & $\begin{array}{l}\text { Derslerde bilgisayar oyunu kullanılarak ders işlemek dersleri daha } \\
\text { eğlenceli hale getirebilir. }\end{array}$ & 4.15 & .79 \\
\hline & 21 & $\begin{array}{l}\text { Derslerde bilgisayar oyunu kullanmak öğrencilerin bilgi ve becerilerini } \\
\text { geliştirmesine yardımcı olabilir. }\end{array}$ & 3.98 & .79 \\
\hline$\overline{\overline{0}}$ & 22 & $\begin{array}{l}\text { Genel olarak eğitsel bir oyunun çalışma mantığını ve algoritmasını } \\
\text { yazabilirim. }\end{array}$ & 3.69 & 1.03 \\
\hline 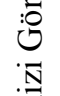 & 23 & $\begin{array}{l}\text { Kendi derslerimde kullanmak üzere bir yazarlık dili ile eğitsel bir oyun } \\
\text { tasarlayabilirim. }\end{array}$ & 3.76 & .98 \\
\hline 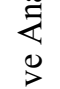 & 24 & $\begin{array}{l}\text { Bulduğum bir eğitsel oyunun derslerim için uygunluğunu } \\
\text { değerlendirebilirim. }\end{array}$ & 4.24 & .65 \\
\hline 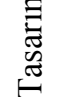 & 25 & $\begin{array}{l}\text { Eğitsel bir oyunun farklı branştaki bir meslektaşım tarafından } \\
\text { kullanılabilirliğini denetleyecek değerlendirme kriterlerini yazabilirim. }\end{array}$ & 3.99 & .78 \\
\hline 寻 & 26 & $\begin{array}{l}\text { Kendi derslerimde kullanmak üzere, internet ortamından eğitsel } \\
\text { oyunlar bulabilirim. }\end{array}$ & 4.35 & .70 \\
\hline 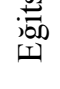 & 27 & $\begin{array}{l}\text { Eğitsel oyunların tasarımını farklı ögrenme kuramlarına dayalı olarak } \\
\text { farklılaştırabilirim. }\end{array}$ & 3.97 & .86 \\
\hline
\end{tabular}

* Bilgisayar oyunlarına yönelik ters maddelerdir.

Tablo 3'te görüldüğü gibi bilgisayar öğretmenlerinin bilgisayar oyunlarını öğrenciler için zaman kaybı olabilme $(\bar{x}=3.84)$ boyutu ile eleştirirken, sosyal becerilerin gelişimine katkı sağlama ( $\bar{x}=3.55)$, öğrenmeye karşı merak uyandırma, her yaş grubundaki öğrenciler için uygun olma, hayatın bir parçası haline gelme şeklindeki 
maddeler içinse kısmen olumlu görüş bildirdikleri görülmüştür. Öğretmenlerin bilgisayar oyunları hakkında bağımlılık tehlikesi, zaman kaybına neden olma, her yaş grubu için kullanımını doğru bulma gibi bazı konularda endişeler taşıdıkları görülmüştür.

Eğitim amaçlı kullanımı konusunda bilgisayar öğretmenleri bilgisayar oyunlarının eğitimde kullanılabilirliğini destekledikleri $(\bar{x}=4.29)$, öğrenmeyi kolaylaştırdığı $(\bar{x}=4.24)$, derse olan ilgiyi $\operatorname{artırdığı~}(\bar{x}=4.16)$, öğretime yardımcı kullanımını destekledikleri ( $\bar{x}=4.08)$, ders programına uyumlu kullanımını önerdikleri $(\bar{x}=4.05)$, dersleri eğlenceli hale getirdiği $(\bar{x}=4.15)$ düşünceleri ön plana çıkan maddeler olmuştur. Tüm öğretim kademelerinde kullanılabilirliği ( $\bar{x}=3.48)$, tüm dersler için kullanılabilirliği $(\overline{\mathrm{x}}=3.48)$, yarış ortamında kullanımının eğitimi pozitif etkileyeceği $(\bar{x}=3.53)$ ve boş zamanları doldurmak için kullanımı $(\bar{x}=3.55)$ bilgisayar oyunlarının eğitim amaçlı kullanımında kısmen olumlu bulunan maddeler olarak dikkati çekmektedir. Genel anlamda eğitsel oyunlar için öğretmenler eğitim programına uygun olarak kullanılması düşüncesi ile eğitimin kalitesini artıracağı, öğrencilerin ilgisini çekeceği, kendi kendine öğrenmeyi artıracağı yönünde bir görüş olduğu buna karşın, tüm dersler ve farklı yaştaki öğrenciler için kullanımları, boş zamanların değerlendirilmesi ve yarış şeklindeki oyun kullanımı için eğitsel yazılımlarda çekincelerin olduğu söylenebilir.

Bilgisayar öğretmenleri bilgisayar oyunlarının tasarımı ve analizi konusunda kendi derslerinde kullanılacak oyunları internetten bulabilme $(\bar{x}=4.35)$, bir oyunun kendi dersleri için uygunluğunu değerlendirme $(\bar{x}=4.24)$, değerlendirme kriterleri yazabilme $(\bar{x}=3.99)$, farklı öğrenme kuramlarına göre farklı oyun tasarlayabilme $(\bar{x}=3.97)$ konularında kendilerini yeterli gördükleri görülmektedir (Tablo 3 ). Kendi derslerinde kullanmak üzere eğitsel oyun yazma konusunda $(\bar{x}=3.76)$ ve eğitsel bir oyunun çalışma mantığı ile algoritma becerisini yazma $(\bar{x}=3.69)$ yeterli görülmekle birlikte diğer maddelere göre daha az ortalama sahip maddeler olmuştur. Bu açıdan öğretmenlerin hazır materyalleri bulma konusunda kendilerini daha yeterli görürken, oyunların mantığı ve yazımı konusunda eğitim ihtiyaçları olduğu şeklinde bir yorum yapılabilir.

\section{Bilgisayar Oyunlarına Yönelik Görüşlerin Eğitsel Bilgisayar Oyunu Konusunda Eğitim Alma Durumuna Göre İncelenmesi}

Araştırma kapsamında eğitsel bilgisayar oyunları konusunda eğitim alan ve almamış olan bilgisayar öğretmenlerinin görüşlerinin farklılaşıp farklılaşmadığı da incelenmiş, elde edilen bulgular Tablo 4'te verilmiştir. 
Tablo 4

Bilgisayar Oyunları Konusunda Ĕ̈itim Alma Durumuna Göre Öğretmen Görüşleri

\begin{tabular}{|c|c|c|c|c|c|c|c|}
\hline Alt Boyutlar & Gruplar & $n$ & $\bar{x}$ & $S d$ & $d f$ & $t$ & $p$ \\
\hline Bilgisayar Oyunları & Eğitim Almamış & 58 & 3.53 & .58 & 117 & 1.037 & .302 \\
\hline Genel Görüşleri & Eğitim Almış & 61 & 3.63 & .49 & & & \\
\hline \multirow{2}{*}{$\begin{array}{l}\text { Eğitsel } \\
\text { Kullanım }\end{array}$} & Eğitim Almamış & 58 & 3.68 & .71 & 117 & 3.627 & $.001 *$ \\
\hline & Eğitim Almış & 61 & 4.07 & .44 & & & \\
\hline Eğitsel Oyun & Eğitim Almamış & 58 & 3.89 & .65 & 117 & 2.081 & $.045^{*}$ \\
\hline Tasarım ve Analizi & Eğitim Almış & 61 & 4.10 & .61 & & & \\
\hline
\end{tabular}

$* p<.05$

Tablo 4'te görüldüğü gibi, eğitsel bilgisayar oyunları eğitimi alan öğrenciler ile bu konuda bir eğitim almamış olan öğrencilere göre sadece eğitsel amaçlı oyun kullanımı konusunda görüşlerde bir farklılık olduğu görülmektedir [ $\mathrm{t}(117)=3.627$, $\mathrm{p}<.05]$. Eğitsel bilgisayar oyunu konusunda eğitim alan öğrencilerin eğitsel amaçl1 kullanım konusundaki madde puan ortalamaları $(\bar{x}=4.07)$ olup, eğitim almamış olanların puan ortalamaları ( $\overline{\mathrm{x}}=3.68$ ) olup iki grup arasındaki fark anlamlıdır. Eğitsel oyun tasarım ve analizi konusunda da iki grup arasındaki fark anlamlıdır [t(117) $=2.081$, $\mathrm{p}<.05]$. Bu konuda eğitim alan öğretmen adaylarının eğitsel oyun tasarım ve analizi konusunda ( $\bar{x}=4.10)$, eğitim almayanlara $(\bar{x}=3.89)$ göre kendilerini daha yeterli gördükleri söylenebilir. Tablo 4 incelendiğinde bilgisayar oyunları genel görüş ortalama puanları açısından eğitim alanların $(\overline{\mathrm{x}}=3.63)$ bu konuda eğitim almayanlara göre $(\bar{x}=3.53)$ yüksek bir puana sahip olduğu görülmektedir. Ancak istatistiki olarak bu fark anlamlı değildir [t(117)=1.037, p>.05].

$\mathrm{Bu}$ bulgu, eğitsel bilgisayar oyunları konusunda verilecek eğitimin, öğretmen adaylarının eğitsel amaçlı oyun kullanımı ve eğitsel oyunların tasarımı ve analizi konusundaki görüşlerini etkileyeceği, ancak bilgisayar oyunları hakkındaki görüşlerinde önemli bir farklılığa neden olmayacağı şeklinde yorumlanabilir.

\section{Bilgisayar Oyunlarına Yönelik Görüşlerin Cinsiyete Göre İncelenmesi}

Araştırma bulguları incelendiğinde, cinsiyetin eğitsel yazılımların kullanımı ve tasarımı açısından önemli bir faktör olduğuna yönelik çalışmalara rastlanmıştır. Kula ve Erdem (2005), araştırmalarında öğretimsel bilgisayar oyunlarının temel aritmetik işlem becerilerinin gelişimine etkisini incelemiştir. Yapılan çalışma sonucunda kız öğrencilerin başarı ortalamalarının arttığı, erkek öğrencilerin başarı ortalamalarının ise düştüğü görülmüştür. İnal ve Çağıltay (2005), araştırmalarında Türkiye'de ilköğretime devam eden öğrencilerin bilgisayar kullanımları ile bilgisayar oyunlarına ve bilgisayar oyunu oynamalarına karşı durumlarını tespit etmeye çalışmıştır. Yapılan çalışma sonucunda kız ve erkek öğrenciler arasında farklılık olduğu gözlemlenmiştir. Aynı 
zamanda erkeklerin kızlara oranla daha fazla oyun oynadıkları tespit edilmiştir. Chou ve Tsai (2007), çalışmasında ergenlik çağındaki öğrencilerin bilgisayar oyunu oynama süreleri, motivasyonları, eğlenceleri ve bilgisayar oyunlarının bu öğrencilerin hayatlarına etkisi konusunda cinsiyetler arasında fark olup olmadığını araştırmıştır. Çalışma sonucunda kızlar ile erkeklerin oyun tercihleri de farklılık göstermiştir. Erkekler strateji ve aksiyon oyunlarını tercih ederken, kızlar ilk sırada bulmaca tarzı oyunları tercih etmektedir.

$\mathrm{Bu}$ bulgular doğrultusunda cinsiyetin bilgisayar öğretmenlerinin eğitsel bilgisayar oyunları konusundaki görüşlerini etkileyip etkilemediği incelenmiş, elde edilen sonuçlar Tablo 5'te verilmiştir.

Tablo 5

Cinsiyete Göre Öğretmenlerin Bilgisayar Oyunları Konusundaki Görüşleri

\begin{tabular}{|c|c|c|c|c|c|c|c|}
\hline Alt Boyutlar & Gruplar & $n$ & $\bar{x}$ & $S d$ & $d f$ & $t$ & $p$ \\
\hline Bilgisayar Oyunları & Erkek & 74 & 3.68 & .53 & 117 & 2.813 & $.006 *$ \\
\hline Genel Görüşleri & Kadın & 45 & 3.41 & .50 & & & \\
\hline \multirow{2}{*}{$\begin{array}{l}\text { Eğitsel Amaçlı } \\
\text { Kullanım }\end{array}$} & Erkek & 74 & 3.96 & .57 & 117 & 1.724 & .087 \\
\hline & Kadın & 45 & 3.76 & .67 & & & \\
\hline \multirow{2}{*}{$\begin{array}{l}\text { Eğitsel Oyun Tasarım } \\
\text { ve Analizi }\end{array}$} & Erkek & 74 & 4.06 & .67 & 117 & 1.271 & .206 \\
\hline & Kadın & 45 & 3.90 & .56 & & & \\
\hline
\end{tabular}

${ }^{*} p<.05$

Cinsiyet sadece bilgisayar oyunlarına yönelik genel görüş boyutunda $[\mathrm{t}(117)=2.813, \mathrm{p}<.05]$ etkili olan bir faktördür. Bu konuda erkeklerin bilgisayar oyunları hakkında olumlu görüşe sahip olduğu $(\overline{\mathrm{x}}=3.68)$ kadınların ise $(\overline{\mathrm{x}}=3.41)$ kısmen olumlu görüşe sahip oldukları görülmektedir (Tablo 5). Ancak eğitsel amaçlı oyun kullanımı [t(117)=1.724, $\mathrm{p}>.05]$ ve eğitsel oyun tasarım ve analizi $[\mathrm{t}(117)=1.271, \mathrm{p}>.05]$ boyutlarında ise cinsiyetin önemli bir faktör olmadığı, kadın ve erkek öğretmen adaylarının aynı düşüncede olduğu söylenebilir.

\section{Bilgisayar Oyunlarına Yönelik Görüşlerin Cep Telefonunda Oyun Oynama} Durumuna Göre İncelenmesi

Cep telefonundan oyun oynayan bilgisayar öğretmen adaylarının oyunlarla daha çok vakit geçireceği düşüncesinden cep telefonlarını oyun amaçlı kullanan ve kullanmayan öğretmen adaylarının bilgisayar oyunlarına yönelik görüşleri karşılaştırılmıştır (Tablo 6). 
Tablo 6

Cep Telefonundan Oyun Oynama Durumuna Göre Öğretmenlerin Bilgisayar Oyunlar Konusundaki Görüşleri

\begin{tabular}{llcccccc}
\hline Alt Boyutlar & Gruplar & $n$ & $\overline{\mathrm{x}}$ & $S d$ & $d f$ & $t$ & $p$ \\
\hline Bilgisayar Oyunları & Oynayan & 76 & 3.66 & .49 & 117 & 2.203 & $.030^{*}$ \\
Genel Görüşleri & Oynamayan & 43 & 3.44 & .58 & & & $.048^{*}$ \\
\hline $\begin{array}{l}\text { Eğitsel Amaçlı } \\
\text { Kullanım }\end{array}$ & Oynayan & 76 & 3.96 & .52 & 117 & 2.016 & \\
\hline Eğitsel Oyun Tasarım & Oynamayan & 43 & 3.74 & .74 & & 1.687 & .104 \\
ve Analizi & Oynamayan & 43 & 3.87 & .59 & & & .65 \\
\hline
\end{tabular}

${ }^{*} p<.05$

Cep telefonundan bilgisayar oyunu oynamanın bilgisayar oyunları genel görüşleri $[\mathrm{t}(117)=2.203, \mathrm{p}<.05]$ ve eğitsel amaçlı kullanımına yönelik görüşler $[\mathrm{t}(117)=2.016, \mathrm{p}<.05]$ üzerinde etkili olduğu; ancak eğitsel oyun tasarım ve analizi boyutundaki görüşlerde $[\mathrm{t}(117)=1.687, \mathrm{p}>.05]$ ise etkisinin olmadığı Tablo 6'dan görülebilir. Cep telefonundan bilgisayar oyunu oynayan öğretmen adaylarının bilgisayar oyunları konusundaki görüş ortalama puanları $(\bar{x}=3.66)$, oynamayan öğretmen adaylarının puanlarından $(\overline{\mathrm{x}}=3.44)$ daha yüksektir. Benzer şekilde eğitsel amaçlı bilgisayar oyunu kullanımı konusunda cep telefonundan oyun oynayan öğretmen adayları $(\bar{x}=3.96)$, oynamayan öğretmen adaylarından $(\bar{x}=3.74)$ daha olumlu düşünmektedirler. Ancak eğitsel oyun tasarım ve analizi noktasında oynayan bireyler ile oynamayan bireyler arasındaki farklılık istatistiki olarak anlamlı değildir.

$\mathrm{Bu}$ bulgu oyunlara yönelik farklı teknolojilere sahip olmanın, öğretmenlerin görüşleri üzerindeki etkisini ortaya koyması açısından önemlidir. Farklı bir teknoloji olan cep telefonları üzerinden oyun oynayan bireyler hem bilgisayar oyunları, hem de eğitsel amaçlı oyun kullanımı konusunda daha olumlu düşünceye sahiptirler.

\section{Sonuç ve Tartışma}

Eğitim öğretimin her kademesinde bilgilerin bir sonraki kuşaklara taşınması açısından oyunlar önemli bir eğitim aracıdır. Oyunlar öğrencilerin kendini ifade etmesi ve yetişkin bireylerin de onu anlamaya çalışması için iyi yol iken aynı zamanda öğrencilerin eğitiminin kendi ellerine bırakıldığı bir tekniktir (Çoban ve Nacar, 2006). Bilgisayar teknolojisinin gelişmesi ve bu teknolojinin entegre edilmesiyle eğitim ortamlarında farklı yöntem ve teknikler kullanılmaya başlanmıştır. Kullanılan bu yöntemlerden biri de bilgisayar oyunlarıdır. Bilgisayar oyunları, öğrenciler için keşfetme ve zengin araçların kullanıldığı sanal ortamlarda gezinme firsatı sağlar ve gerçek dünyaya transfer edilebilecek alıştırma becerileri için doğru içerikler oluşturur (Wheeler, 2009). Eğitim ortamlarında bilgisayar oyunu kullanacak öğretmenlere de 
önemli görevler düşmektedir. Öğretmenler eğitimin hedeflerine ulaşması için gerek oyunları gerekse de bilgisayar oyunlarını etkili bir şekilde kullanmalıdırlar.

Bilgisayar öğretmen adayları bilgisayar oyunlarının bağımlılık riski, zaman kaybına neden olma, her yaş için kullanımının doğru bulmama gibi konularda olumsuz yanlarının ifade etmişlerdir. Ancak hayatın artık bir parçası olduğu da ifade edilmiştir. Haris (2001) çalışmasında bilgisayar oyunun olumsuz etkilerinden biri olarak oyun bağımlılığı üzerinde durmuştur. Chiu, Lee ve Huang (2004) Tayvan'daki çocuk ve gençler üzerinde gerçekleştirdiği çalışmasında cinsiyet ve akademik başarı ile oyun bağımlılığı arasında ilişki olduğunu bulmuştur. Horzum (2011) ilköğretim öğrencilerinin bilgisayar oyun bağımlılık düzeylerini çeşitli değişkenlere göre incelemiştir. Çalışmanın sonunda erkek öğrencilerin kız öğrencilere göre, üst sosyoekonomik düzeye sahip öğrencilerin orta ve alt sosyo-ekonomik düzeye sahip öğrencilere göre daha yüksek oyun bağımlısı olduğu sonucuna ulaşmıştır. Kert ve Kuzu (2006) bilgisayar oyunlarının öğrencilerin üzerindeki etkinliğini sorgulamıştır. Araştırmaya katılan öğrencilerin bir kısmı bilgisayar oyunlarının tek eğlenceleri olduğunu, bir kısım öğrenci ise alışkanlıkları olduğunu, bir kısım öğrenci de bilgisayar oyunlarının hayatlarında zaman kaybı olduğu ifade etmişlerdir. Bu sonuç BÖTE öğretmen adaylarının literatürde yer alan bilgisayar oyunlarına yönelik olumsuzlukların farkında olduklarını ortaya koyması açısından önemlidir.

Eğitsel amaçlı kullanımı konusunda ise eğitimde kullanımını destekledikleri, öğretime yardımcı olacağ 1 ve eğlenceli hale getireceği, motive edici bir rol üstleneceği, öğrenmeyi kolaylaştırdığı genel düşünceler olarak ön plana çıkmıştır. Bu bulgu Tüzün, Yılmaz, Karakuş, İnan ve Kızılkaya (2006), Güneş (2010), Korkusuz (2012), Yağız (2007), Chou ve Tsai (2007), Lim, Nonis ve Hedberg (2006), Hwang, Wu ve Chen (2012), Çankaya ve Karamete (2008) ile tutarlıdır. Tüzün ve diğerleri (2006) kıtalar ve ülkeler konusunu öğretmek amaciyla Quest Atlantis oyununu öğrenciler üzerinde denemişler ve öğrencilerin basarı ve motivasyon düzeylerindeki değişimleri incelemişlerdir. Çalışmanın sonucunda: istatistiksel olarak anlamlı öğrenme gerçekleştiği ve istatistiksel olarak anlamlı bir motivasyon artışı ortaya çıktığ belirtilmektedir. Çankaya ve Karamete (2008) ilköğretim öğrencilerine yönelik matematik dersinin oran orantı konusu ile ilgili eğitsel bilgisayar oyun geliştirerek oyunun öğrencilerin eğitsel bilgisayar oyunları hakkındaki tutumları incelemişlerdir. Çalışmanın sonunda öğrencilerin eğitsel bilgisayar oyunlarına olan tutumları pozitif çıkmıştır. Buna karşın öğretmenler tüm eğitim kademelerinde ve tüm dersler için kullanılabilirliği konusunda kısmen olumlu görüş bildirmişlerdir. Benzer şekilde öğrencileri yarış ortamına sokma amaçlı veya boş zamanları doldurmak amaçlı kullanım yine öğretmenlerin eğitsel amaçlı kullanımı konusunda düşük ortalamaya sahip konular olmuştur.

Tasarım ve analiz konusunda öğretmen adayları daha çok hazır materyallerin internetten bulunması, bunların etkililiğinin değerlendirmesi veya değerlendirme kriteri oluşturma şeklinde diğer kişilerin tasarımlarının analizleri konusunda daha yeterli 
görürken, kendilerinin yapacağı tasarımlar oluşturma boyutunda kısmen daha az yeterli gördükleri söylenebilir.

Eğitsel bilgisayar oyunları konusunda eğitim almak, bilgisayar oyunlarının farklı boyutları konusunda öğretmenlerin görüşlerini etkilemektedir. Özellikle eğitim amaçlı ve eğitsel oyun tasarım ve analizi boyutları alınan eğitimden etkilenirken, bilgisayar oyunları geneli bu eğitimden etkilenmemektedir. Özellikle verilen eğitimin eğitsel oyun odaklı olduğu düşünülürse, bu sonucun çıkması doğal karşılanabilir. Bu açıdan eğitsel bilgisayar oyunları konusunda verilecek eğitimin bilgisayar öğretmen adaylarının bilgisayar oyunlarını eğitim sürecine dâhil etmede önemli olacağı vurgulanmalıdır.

Cinsiyet eğitsel amaçlı oyun kullanımı ve eğitsel oyun tasarım ve analizi konusundaki görüş ve yeterlikler açısından önemli bir faktör değildir. Hem kadın hem de erkek öğretmen adayları oyunun eğitim amaçlı kullanımında aynı görüşe sahiptir. Ancak bilgisayar oyunları geneli açısından erkek öğretmen adayları daha olumlu görüşe sahiptir. Örneğin kadınlar bağımlılık riskini daha fazla bulurken, erkekler daha düşük bulmakta, erkekler sosyal becerilerin gelişmesini sağlama konusunda bilgisayar oyunlarını kadınlara oranla daha çok desteklemektedirler.

Son olarak cep telefonundan oyun oynamanın bilgisayar oyunlarına yönelik genel boyuttaki ve eğitsel amaçlı kullanım boyutundaki görüşleri etkilediği bulunmuştur. Farklı bir teknoloji olan ve gittikçe yaygınlaşan cep telefonuna sahip olan öğretmen adayları, bilgisayar oyunları konusunda daha olumlu düşünmektedir. Benzer şekilde eğitsel amaçlı kullanımını daha çok desteklemektedir. Bu bulgu oyun oynanacak ve pratik anlamda sürekli el altında bulundurulabilecek teknolojiye sahip olmanın önemini göstermektedir. Yaygın olarak cep telefonu üzerinden oyunlarla daha çok vakit geçiren bireyler, oyunlara yönelik daha olumlu görüşe sahiptir. Günümüz öğrencilerinin cep telefonu gibi teknolojilerini yaygın ve etkin bir şekilde kullanıldığı düşünülürse, öğretmenlerin bu yeni teknolojileri onların ilgisini çekecek düzeyde kullanmalarının önemi de anlaşılabilir. Özellikle bilgisayar öğretmenlerinin cep telefonlarını eğitsel oyunlarla bir öğrenme ortamına dönüştürmeleri gerekir. Ancak araştırmada eğitsel oyun tasarımı konusunda cep telefonundan oyun oynayan bireylerin tasarımı veya analizi daha iyi yaptıkları yönünde bir bulguya rastlanamamıştır. Cep telefonu ile oyun oynayan bilgisayar öğretmen adaylarının genellikle masaüstü veya dizüstü bilgisayar ortamında tasarım yapıyor olmaları, henüz cep telefonu ortamında oyun yapma konusunda eğitim almamış olmaları bu farklılığın çıkmasını engellemiş olabilir. Bu yönde eğitim verilmesi önerilebilir.

\section{Öneriler}

Eğitim sistemleri kaliteli eğitsel yazılımlara ihtiyaç duymaktadır. Bu yazılımlardan biri de bilgisayar oyunlarıdır. Bu yazılımları seçecek, tasarlayacak ve kullanımına rehberlik edecek bireyler olarak bilgisayar öğretmenlerine önemli görevler düşmektedir. Öğretmen eğitim sürecinde BÖTE bölümünde öğrenim gören bilgisayar öğretmen adaylarına bu eğitimin verilmesi de önem taşımaktadır. Araştırma sonuçları da bu konuda verilen eğitimin etkili olduğunu ortaya koymuştur. BÖTE eğitim 
programlarında bu konuda seçmeli derslere yer verilebilir. Ayrıca cep telefonundan oyun oynayan öğretmen adaylarının daha olumlu görüş bildirmeleri, bilgisayar oyunlarına yönelik seçmeli derslerin içeriğinde popüler farklı teknolojik araçların da işe koşulmasını önemli hale getirmektedir. Bu derslerin günün ihtiyacına yönelik yazılım ve donanımları içeren farklı teknolojileri dikkate alacak şekilde yapılandırılması önerilir.

\section{Kaynakça}

Akpınar, Y. (1999). Bilgisayar destekli öğretim ve uygulamalar. Ankara: Anı Yayınc1lik.

Chiu, S. I., Lee, J. Z., \& Huang, D. H. (2004). Video age addication in children and teenagers in Taiwan. Cyber Psychology \& Behavior, 7(5), 571-581.

Chou, C. \& Tsai, M. J. (2007). Gender differences in Taiwan high school students' computer game playing. Computers in Human Behavior, 23, 812-824.

Çankaya, S. \& Karamete A. (2008). Eğitsel bilgisayar oyunlarının öğrencilerin matematik dersine ve eğitsel bilgisayar oyunlarına yönelik tutumlarına etkisi. Mersin Üniversitesi Ĕ̈itim Fakültesi Dergisi, 4(2), 115-127.

Çankaya, S. \& Karamete, A. (2008). Eğitsel bilgisayar oyunlarının öğrencilerin matematik dersine ve eğitsel bilgisayar oyunlarına yönelik tutumlarına etkisi. Mersin Üniversitesi Eğitim Fakültesi Dergisi, 4(2), 115-127.

Çoban, B. \& Nacar, E. (2006). Okul öncesi eğitimde eğitsel oyunlar, Ankara: Nobel Yayın Dağıtım, 18-23,29.

Garris, R., Ahlers, R., \& Driskell, J.E. (2002). Games, motivation, and learning: A research and practice model. Simulation and Gaming, 33, 441-467.

Güneş, H. (2011). Geliştirilen çevrimiçi elektrogame oyununun ilköğretim 4. basamak bilişim teknolojileri dersi başarısına etkisi. (Yayımlanmamış yüksek lisans tezi). Balıkesir Üniversitesi, Fen Bilimleri Enstitüsü, Balıkesir.

Harris, J. (2001). The effects of computer games on young children: A review of the research. Journal of Amer Academi of Child Adolescent, (72), 22.

Horzum, M.B. (2011). İlköğretim öğrencilerinin bilgisayar oyunu bağımlılık düzeylerinin çeşitli değişkenlere göre incelenmesi. Ĕ̌itim ve Bilim, Cilt 36, Sayı 159, ss. 56-68.

Hwang, G.-J., Wu, P.-H., \& Chen, C.-C. (2012). An online game approach for improving students' learning performance in web-based problem-solving activities. Computers \& Education (59), 1246-1256.

İnal, Y. \& Çağıltay, K. (2005). Turkish elementary school students’ computer game play characteristics. International Informatics Congress, Eskisehir, 10-12.

Kert, S. \& Kuzu, A. (2006). Lise öğrencilerinin bilgisayar oyunu tercihleri ve oyun oynama alışkanlıkları. 6th International Educational Technology Conference. Eastern Mediterranean University, Famagusta, North Cyprus, 19-21 Nisan, 2, 10971106. 
Kokusuz, M. E. (2012). Elektromega eğitsel oyunun tasarlanıp geliştirilerek basit elektrik devreleri konusunda bilişsel ve duyuşsal değişkenlere etkisinin incelenmesi. (Yayımlanmamış yüksek lisans tezi). Balıkesir Üniversitesi, Fen Bilimleri Enstitüsü, Balıkesir.

Kula, A. \& Erdem, M. (2005). Öğretimsel bilgisayar oyunlarının temel aritmetik işlem becerilerinin gelişimine etkisi. Hacettepe Üniversitesi Ĕ̆itim Fakültesi Dergisi, 29, 127-136.

Lim C. P., Nonis D., \& Hedberg J. (2006). Gaming in a 3d multiuser virtual environment: engaging students in science lessons. British Journal of Educational Technology, 37(2), 211-231.

Prensky, M. (2001). Digital game-based learning. New York: McGraw-Hill.

Tüzün, H., Yılmaz, M., Karakuş, T., İnal, Y., \& Kızılkaya, G. (2006). Bilgisayar oyunlarının öğrencilerin öğrenme ve motivasyonuna olan etkileri. Akademik Bilişim 2006 Konferansı, Denizli, Türkiye.

Ward, L. (2004). Computer games can help children learn. The Guardian Wednesday, October 27.

Wheeler, S. (2009). Connected minds, emerging cultures: cybercultures in online learning. Retrieved from: http://books.google.com.tr/books?id=kbH5H7iZ9kC\&pg=PA78\&dq=educational+computer+game\&lr=\&as_brr=3\#v=onepage $\& q=$ educational\%20computer\%20game $\& \mathrm{f}=$ false.

Yağız, E. (2007). İlköğretim öğrencilerinin bilgisayar dersindeki başarıları ve özyeterlik algıları üzerine etkileri. (Yayımlanmamış yüksek lisans tezi). Hacettepe Üniversitesi, Ankara. 